\title{
Korai idegrendszeri károsodások: korai diagnosztika, prognózis és terápia
}

\author{
Dr. Berényi Marianne - Dr. Katona Ferenc \\ Fejlődésneurológiai Osztály, Szent Margit Kórház, Budapest
}

\begin{abstract}
A korai - részben veleszületett - idegrendszeri károsodások felismerése, az agy morfológiai és funkcionális állapotának a megítélése, a prognózis megállapítása és a szükséges terápiák bevezetése rendkívül felelösségteljes orvosi feladat. A központi idegrendszer fejlődése születés után a humán genetikai program és a külső hatások alapján tovább folyik. A fö kérdés, hogy az elszenvedett károsodások mennyiben befolyásolhatják mindezt, hogyan és milyen irányban változtathatják ezt a folyamatot. Mind a mozgás, mind a figyelem és az értelem az emberre jellemző humán specifikus, együttes kialakulása ettől az agyi fejlődéstől függ. A korai diagnózisnak és prognózisnak a meglévő és a várható károsodásokra kell következtetnie ahhoz, hogy a szükséges, megelöző terápia időben megindulhasson. A következőkben elöször a diagnosztikai és terápiai módszereket foglaljuk röviden össze, mert metodikai leírás nélkül semmiféle módszer alkalmassága, hatékonysága nem itélhető meg.
\end{abstract}

Kulcsszavak: fejlődésneurológia, neuroterápia, elemi mozgásminták, szenzoros tréning, idegfelöli elektroterápia, szülők tanítása

A korai fejlődésneurológiai vizsgálatok egyaránt magukba foglalják a figyelem-, az értelem- és a mozgás-fejlődésének egymással összefüggö folyamatát. Mind a központi-, mind a perifériás idegrendszert érhetik olyan károsodások, a magzati életben, vagy a születés kapcsán, amelyek ennek az összefüggő folyamatnak a korai szakaszában történnek és befolyást gyakorolnak a folyamat későbbi lezajlására. Minden esetben meg kell fontolni, hogy a perifériás idegek, a gerincvelö, az agytörzs illetve a nagyagy egymással összekapcsolódó müködése kóros esetben milyen hatást gyakorol a felnövekvő csecsemő, kisded, gyermek, serdülö és felnőtt életvitelére, illetve társadalmi beilleszkedésére. A korai diagnózisnak, prognózisnak és terápiának mindezt messzemenően figyelembe kell vennie. Az újszülött agy genetikai programjai magukban foglalják az agy későbbi fejlődése során kialakulható értelmi-, érzelmi-, érzékszervi- és mozgásfunkciók elemi mintázatait. Ezekböl alakulnak ki a viszonylag hosszú csecsemő-, kisded- és gyermekkorban az emberre jellemző végleges érzékszervi-, értelmi-, érzelmi- és mozgásbeli mintázatok. A korai fejlődésneurológiai diagnosztika és prognosztika ezeknek az összetett korai agymüködési mintázatoknak alapján állapítja meg, hogy az elszenvedett genetikai, vagy külső változás (például oxigénhiány, vagy vérzés) milyen folyamatokat indított be és milyen korai terápiára van szükség a következmények kivédésre.

Az osztály tevékenységének egyik része - a különböző objektív vizsgálatok alapján - annak megállapítása, történt-e valamilyen agyi károsodásra utaló folyamat és ennek milyen bizonyítékai vannak. Továbbá veszélyeztetheti-e a kialakult morfológiai és/ vagy fiziológiai elváltozás a csecsemő további fejlődését. Amennyiben a fejlődés veszélyeztetettnek látszik, akkor ennek a prognózisnak alapján egyéni kezelést, neuroterápiát kell kezdeni. A továbbiakban rendszeresen ellenőrizni kell - járóbeteg-rendelés kapcsán - a beteg fejlődését. Amennyiben a kóros morfológiai elváltozás nem okozott semmiféle károsodást a csecsemő figyelmi, értelmi, mozgásbeli funkcióiban, úgy semmiféle kezelésnek, tornának vagy fejlesztésnek, illetve intervenciónak nincsen létjogosultsága! 
A fejlődésneurológia kifejezés és szakmai ágazat természetes módszere a felnövekvő csecsemő rendszeres ellenőrzése. Ezt maga a fejlődési folyamat adaptációs funkciója is fontossá teszi, mert a vizsgált funkciók, mint például a figyelem összetettségének módosulásai lényegében már az értelmi fejlődés nélkülözhetetlen összetevői. Kizárólag rendszeresen ismételt vizsgálatokkal lehet megállapítani, hogy az agyi károsodás milyen hatást gyakorol a különböző funkciók kialakulási folyamataira, illetve hogy az alkalmazott kezelés megelőzi-e az ilyenfajta káros következmény kialakulását. A figyelmi- és a korai értelmi müködés egyúttal a kommunikáció előfeltétele és a terápia egyik fontos célja a kommunikáció mielőbbi kiépítése. A Fejlődésneurológiai Osztály mintegy másfél - két évig ellenőrzi az osztályon kivizsgált és kezelésben részesített csecsemők értelmi, érzelmi, érzékszervi és mozgásfejlődését. A vizsgálatok eredményének értékelése alapján, szükség esetén a csecsemő állapotának és korának megfelelő újabb kezelési eljárásokat oktatunk a szülőknek és a következő vizsgálatot ennek alapján végezzük. A Fejlődésneurológiai Osztályon tehát folyamatos klinikai nyomon követés történik a folyamat egyes szakaszainak havi, rendszeres ellenőrzésével.

A figyelmi funkciók korai vizsgálata: Vizuális figyelem vizsgálata: A figyelem vizsgálata magába foglalja a szemmozgató idegek müködésének, a látószervek összpontosításának, illetve az összpontosítás időtartamának megítélését, valamint a vizuális figyelem felkeltésének módját (arccal, az archoz hasonló ábrákkal, színes, illetve fekete-fehér, kontrasztos képekkel mozgó, illetve egyhelyben lévő tárgyakkal.) Fontos a tárgyakra, illetve a személyekre vonatkozó figyelem irányulásának megítélése. A vizsgálathoz a személyes megfigyelésen és az időmérésen kívül felhasználjuk a számítógépes programokkal vezérelt poligráf vizsgálatot is. Ennek az az előnye, hogy a figyelem neurofiziológiai funkcióján, az orientáción kívül vizsgálhatjuk a megszokást, a habituációt is. A vizsgálat során hasonló intenzitású, de frekvenciában különböző inger hatására újabb orientáció, azaz diszhabituáció alakul ki. Ezzel a módszerrel egyúttal a rövid memória is vizsgálhatóvá válik, mert a csecsemő ennek alapján különbözteti meg a már habituált folyamat megváltozását. Tekintettel arra, hogy ezek a figyelmi folyamatok egyúttal a kommunikáció előkészítői is, az is megfigyelhető, hogy mennyire változik az optikai illetve auditív figyelem nyugalmi helyzetben illetve fontos elfoglaltságok alatt, mint amilyen a táplálkozás.
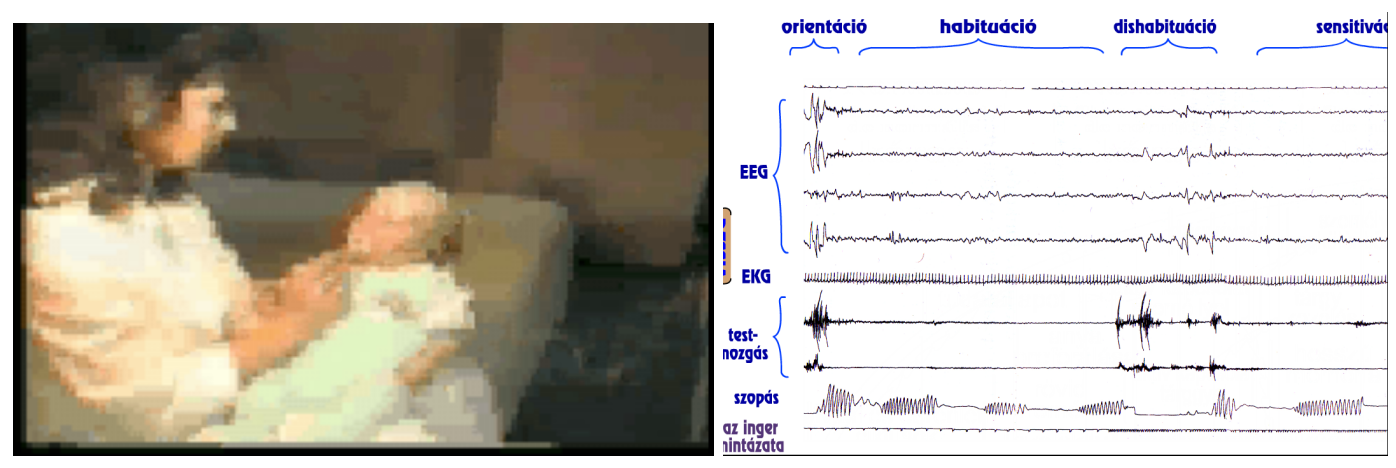

1. kép: Polygraphiás vizsgálat (az agyi elektromos tevékenység, a szívritmus, a mozgás és az etetéssel nem összefüggő szopás egyidejü, többcsatornás vizsgálata fény-, ill. hanginger adása közben)

Az optikai, illetve az auditív figyelem vizsgálatának természetes előfeltétele a hallás illetve a látás épségének megállapítása. Ez különösen fontos minden olyan 
csecsemő esetében, akinek az anamnézisében hypoxia illetve asphyxia szerepel, vagy az előzetes neonatológiai vizsgálatok, illetve saját vizsgálataink morfológiailag értékelhető agyi károsodást mutattak ki. Az érzékszervek az agy kihelyezett részei, valódi működésüket a belölük az agy elsődleges, unimodális és multimodális neuronhálózataihoz az agyidegeken át érkező ingerületek feldolgozása teszi lehetővé. Éppen ezért elengedhetetlen a fejlődésneurológiai diagnózis, illetve prognózis felállításához az érzékszervekből beérkezett ingerületeket feldolgozó rendszerező és összefoglaló agyi területeknek a vizsgálata. A vizsgálathoz alkalmazott elektrofiziológiai technikák az agykérgi, illetve az agytörzsi kiváltott potenciál vizsgálatok. Ezek a technikák nemcsak azt ellenőrzik, hogy a fizikai ingereket, fiziológiai ingerületté átalakító érzékszervek megfelelően működnek-e, hanem azt is, hogy az elsődleges ingerület felvevő agyterületek miképpen fogadják a beérkező specifikus ingerületeket. Ettől is függ, hogy ezután a specifikus multimodális, asszociációs területek hogyan dolgozzák majd információkká az ingerületeket. Az agytörzsi kiváltott potenciál vizsgálat egyúttal megvilágítja, hogy milyen a vizsgált csecsemő éberségi szintje és ez a szint mennyiben függ az agytörzs éberségi rendszerébe érkező, majd onnan részben a thalamuson át a cortexhez jutó, az érzékszervekből származó, nem specifikus ingerületektől.

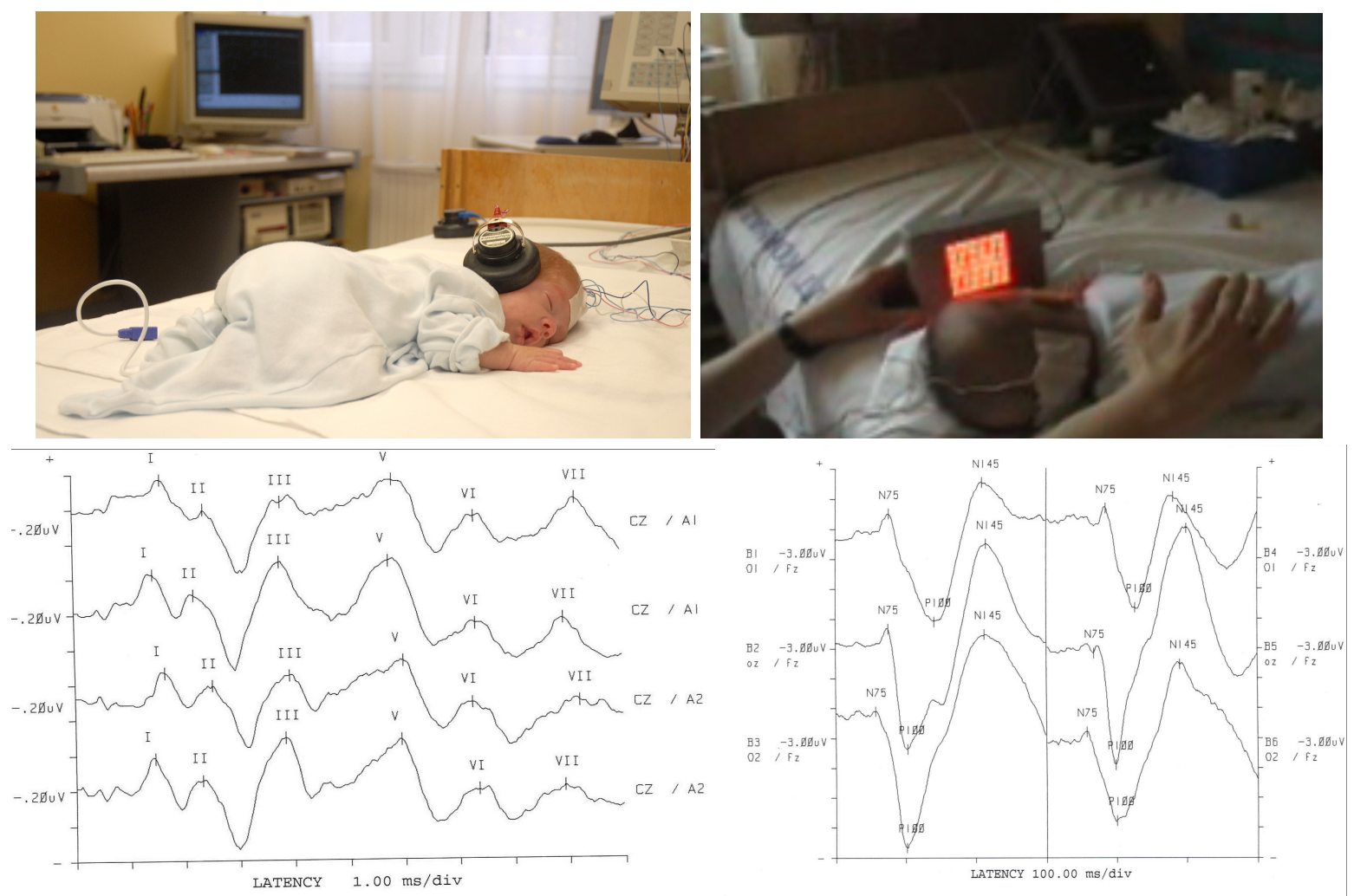

2. kép: Kiváltott potenciálvizsgálat hanginger (bal oldali kép) és vizuális inger (jobb oldali kép) adásakor (a kivitelezés módja alatt láthatók a görbék¹).

A figyelmi és a precognitív funkciókárosodások neuroterápiája: A figyelmi funkciók felkeltésének és fenntartásának első, legfontosabb követelménye az emberi arcra figyelés felkeltése. Erre a célra elsősorban a valódi emberi arc, az édesanya,

\footnotetext{
${ }^{1}$ A hang agytörzsi kiváltott válasz csúcsait római számokkal jelzik (I-töl VII-ig), ezek a hallópálya átkapcsolódási helyeinek felelnek meg. A fény ingerre kiváltott kérgi válasz (VEP) három jellegzetes csúcsát a kitérés irányával ( $N$ = negatív, $\mathrm{P}=$ pozitív) és az inger adásától eltelt milliszekundum arab számával jelzik (N75, P100, N145).
} 
illetve a családtagok arca a legalkalmasabb, azonban az arcokat a csecsemő látóterében viszonylag közelebb kell tartani, két-három perc időtartamra. Ez történhet félig ülő, fekvő vagy oldalt fekvő helyzetben. Hason fektetéskor a vizuális figyelem felkeltésére nyakmozgás is szükséges, ami fokozza a szemmozgató izmok aktivitását. Az agy müködése együtt kezeli a fejmozgatását a szemmozgató izmok mozgatásával. $A$ szemek ezért folyamatosan alkalmazkodnak a fej helyzetéhez. Ennek alapján minden olyan testmozgás, amely a fej mozgatásával jár, magában foglalja a látás-, illetve a vizuális figyelem működését. Amennyiben a csecsemő kezeléshez a mozgásminták gyakoroltatása szükséges, akkor előnyös a levegőbe emeléskor valamelyik családtag arcának mutatása és kombinálása a mozgásgyakorlattal. A figyelem felkeltésére szóló gyakorlatokat minden nap kell végezni, különböző napszakokban néhány percig.

\section{A mozgásfejlődés károsodásának kivizsgálása}

Testhelyzet és testhelyzet-változtatás: Minden mozgás és testhelyzet-elfoglalás a gravitációs térben történik és ezért a harántcsíkolt izomműködés idegi szabályozásának egyik feladata a gravitáció folytonos ellensúlyozása. Nagyjából ez az, amit egyensúlynak nevezünk, és ez a csecsemő mozgás-dinamikájának egyik nélkülözhetetlen alapja. A gravitációs tér és változásainak hatását a koponya két oldalában lévő érzékszervek, a labirintusok alakítják át ingerületté és ezeket a vesztibuláris rendszer juttatja el elöször a nyúltvelö speciális neuroncsoportjaihoz, a vesztibuláris magvakhoz és innen a gerincvelő mozgató magvaihoz. A két vesztibuláris pálya közvetíti a labirintusban keletkező és a vesztibuláris magvakban átalakított ingerületeket a gerincvelő mozgató idegsejtjeihez. Az agyból érkező és mozgást indító ingerületek itt a gerincvelőben egyesülnek az egyensúlyozást biztosító vesztibuláris ingerületekkel. Az egyensúlyozás még a legkisebb mozgásba is bekapcsolódik, hiszen minden mozgás a gravitációs térben zajlik. Az egyensúlyozó, vesztibuláris ingerületek másodperc töredékekkel megelőzik a mozgásmüködést, annak érdekében, hogy semmi se veszélyeztethesse az egyensúlyt. A nyúltvelő vesztibuláris magrendszeréből egy másik pálya az agytörzs szemmozgást szabályozó idegsejt csoportjaihoz, magvaihoz szállítja a labirintus ingerületeit és ezek segítik elő, hogy a szemek mindig egymással koordinálva és mindig elöre nézzenek.

Elemi mozgásminták: Mint minden agyműködésnek a mozgásnak is van újszülöttekben és fiatal csecsemőkben speciális mintázata, mely az egyensúlyrendszer ingerlése útján aktiválható. Az elemi mozgások magukban foglalják a kúszástól a két lábon járásig tartó humán mozgásfejlődési folyamathoz szükséges mozgásokat. Ezek olyan testhelyzetekben válthatók ki, amelyben a koponyában lévő labirintus térbeli helyzete megváltozik. A csecsemő átlagos helyzete a vízszintes, horizontális fekvés, amely csak a mamával való kapcsolat közben változik táplálásnál, mosdatásnál, öltöztetéskor, vetkőztetéskor, illetve testen hordásnál, ami ma séta, bevásárlás, ügyintézés kapcsán divatossá vált. (kenguru, hordozókendő, mei tai stb.) Az elemi mozgásminták kiváltásához a csecsemőt különféle testhelyzetekbe kell hozni, hogy minden egyes elemi mozgásmintázat aktiválódhasson.

A két lábon járás és az egyenes testtartás az ember speciális testhelyzete és mozgása a gravitációs térben. Ennek kialakulása több mint 10 hónapig tart, azonban mód van arra, hogy megvizsgáljuk, mennyire készült fel az újszülött, illetve a fiatal csecsemő ennek a genetikai programnak a kivitelezésére. A csecsemőt ehhez a vizsgálathoz két combjánál fogva óvatosan a levegőbe emeljük és hátát a mellkasunkhoz támasztjuk, ebből a helyzetből előre emeljük. A csecsemő így támasz nélkül marad és gravitáció ebben a helyzetben gyakorol rá hatást. A támasz nélkül, a levegőbe kiültetett csecsemő előre hajlik, ami a labi- 
rintust kimozdítja és ebben a helyzetben méri a rá ható gravitációs erőt. Ez a labirintusban, majd az előbb leírt módon a nyúltvelő vesztibuláris magvaiban speciális ingerületi állapotot kelt, ami innen a gerincvelő mozgató sejtjeihez jutva azonnal az egyensúlyozással kapcsolatos ingerületeket kelt. Ehhez azoknak az izomcsoportoknak müködése szükséges, amelyek ellensúlyozhatják a gravitációs erőt. Ilyenek a törzs izmai, amelyek kiegyenesítik a törzset, és a nyakizmok, amelyek a fejet a törzs tetejére emelik és ott megtartják. A csecsemő elörehajlása után néhány másodpercen belül ez következik be, a csecsemő felül és emelt fejjel egy-két másodpercig ülve marad. Ebben a helyzetben a gravitációs erő újra hatást gyakorol rá és ismét elöre görnyed. A labirintus újra müködésbe lép és a csecsemő hamarosan újra felül. Ebben a vizsgálati helyzetben megítélhető mennyire egyenesedik fel a csecsemő és hogyan tartja a fejét. Ez napszakokon belül is változhat, ezért a Fejlődésneurológiai Osztályon a csecsemőt több napon át ismételten meg kell vizsgálni különböző napszakokban. Ennek alapján mérlegelhető károsodott-e a felegyenesedési, vertikalizációs mozgásdinamika és indokolt-e a csecsemőt ebben az irányban terápiában részesíteni. Az egyenes testtartás és a fej fenntartása a törzs tetején későbbiekben az ülés, az állás és a járás nélkülözhetetlen tartozéka lesz, mint az emberré válás egyik legfontosabb fejlődési hozama. Éppen ezért rendkívül fontos annak megállapítása, hogy az agy károsodása nem veszélyezteti-e ennek a funkciónak kialakulását. Az ülő helyzetben az is vizsgálható elöre néznek-e ilyenkor a szemek, nincs-e ebben valamilyen elváltozás.

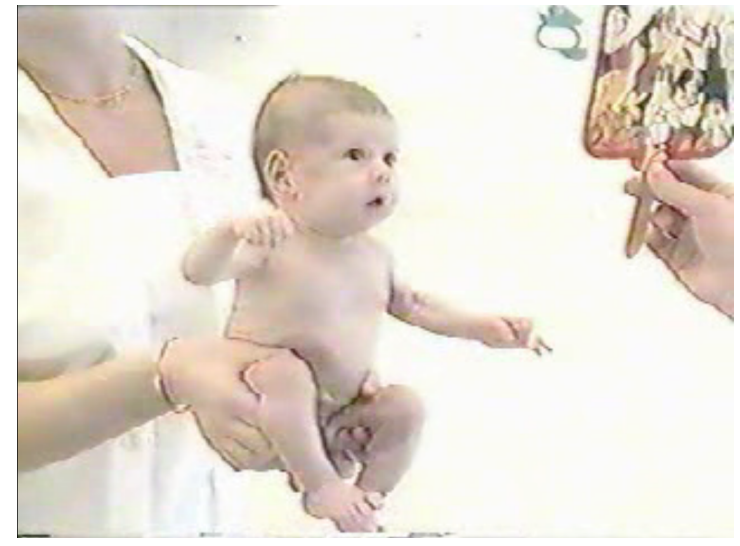

3. kép: A levegőben ülés elemi mozgásmintája 6 hetes csecsemőben

Egy másik fontos elemi mozgásminta úgy váltható ki, ha a csecsemőt egy kb. $30^{\circ}$ párnázott deszkaalapból álló kis lejtőre helyezzük fejjel lefelé. A lejtő, nem csúszda, nem annyira meredek, hogy csúszást indítson. A csecsemő ezen a kisfokú meredeken ferdén lefelé irányuló helyzetbe kerül, ami a koponyában megváltoztatja a labirintusok helyzetét. Ennek hatására olyan mozgások keletkeznek, amelyek kompenzálási müködése ismét vízszintes helyzetbe hozza a csecsemőt a lejtő végén. A csecsemő a kisfokú lejtőn nem tud csúszni, hanem kúszó mozgásba kezd. A kúszás mozgásmintájának leglényegesebb része a csípők és az alsó végtagok ismételt mozgása. A mozgás energiája lefelé viszi a csecsemőt a párnázott deszkalapon. Ez az elemi mozgásminta lényegében a csípők és az alsó végtagok folyamatos hajlításából és nyújtásából áll, ami lökésszerüen elöreviszi a csecsemőt. A két végtag hol szimmetrikusan, hol aszimmetrikusan müködik. Az utóbbi esetben az egyik végtag hajlított, a másik végtag átmenetileg nyújtott helyzetben van. Ez a mozgás folyamatos, de időnként megszakadhat és ilyenkor a csecsemő fekve marad, majd rövidebb szünet után folytatja a mozgást, amíg le nem ér a lejtő aljára, ahol a padló, vagy az asztal már vízszintes és a mozgás ilyenkor hamarosan abbamarad. 


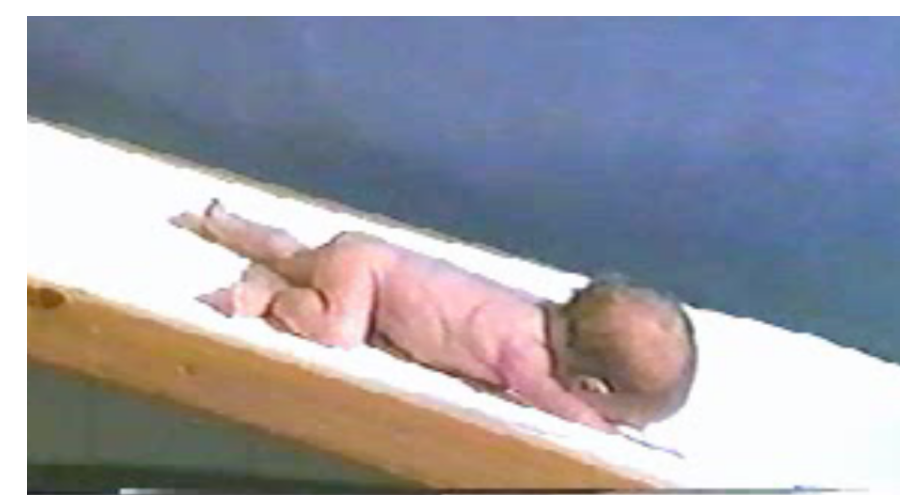

4. kép: Az önálló (lejtőn lefelé) kúszás elemi mozgásmintája

Ugyancsak az elemi mozgások csoportjába sorolható a régebben is ismert lépegetés, az elemi járás. Összehasonlítva a kúszással a lépegetésnek is fő mozgásdinamikai része a csípők és az alsó végtagok felváltott, ritmikus müködése. Egy újszülöttet, vagy fiatal csecsemőt asztalra állítva a két alsó végtagja egy idő után kifeszül és a törzs is egyenesedik. A csecsemőt természetesen ebben a helyzetben két oldalánál fogva a mellkas táján meg kell tartani, mert önállóan nem tud a gravitáció ellenében állva maradni. A törzs nagyon kisfokú elöremozdításával a fej is elmozdul egyenes helyzetéből és a labirintusok ingerületbe kerülnek. Ebben a vertikális helyzetben, ugyanúgy, ahogy ferdén hason fekve kúszás jön létre, ebben az álló helyzetben lépegetés alakul ki. Az egyik végtag feszített, nyújtott helyzetben, merev állapotban támaszkodik, a másik pedig egyidejüleg csípőben és térdben hajlítva felemelkedik. Akárcsak kúszás közben ezek a mozgások is folyamatosan zajlanak le, ameddig a lépegető csecsemő két oldalánál fogva elöre visszük a mozgás követésére. Lépegetés közben is előfordulhat megállás, szünet, majd a mozgás folytatása következik, de az is megtörténhet, hogy a csecsemő a vertikális helyzetböl kissé összecsuklik, és maga alá kapja a lábait. Rövid szünet után a vizsgálat folytatódhat.

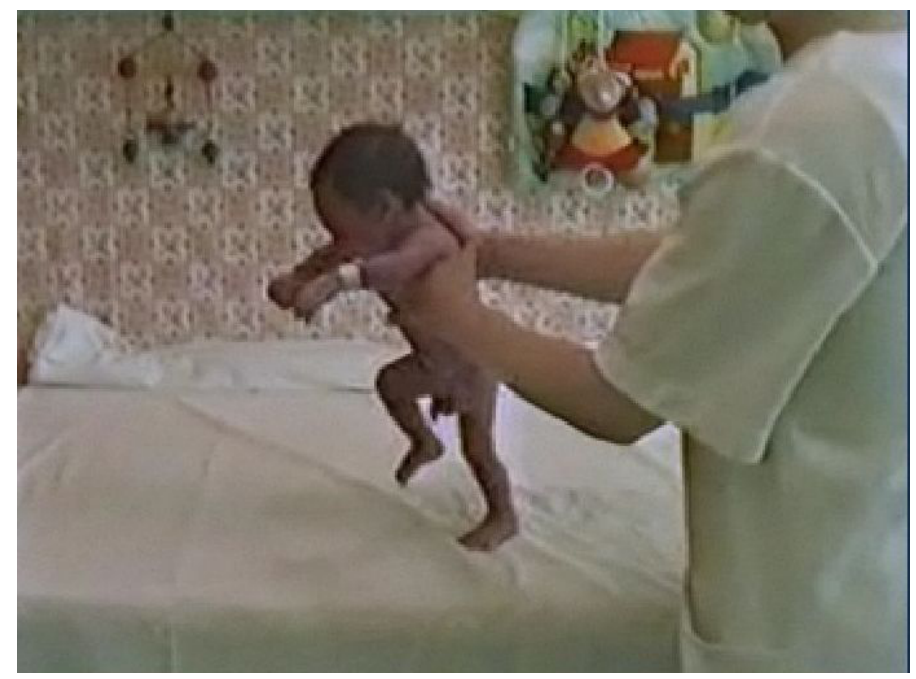

5. kép: Az elemi járás

A csecsemő későbbi forgáskészségének előzetes vizsgálata a következőképpen történik. A csecsemőt takarón, pelenkán hátára fektetjük és ebből a helyzetből a takaró fej felé eső részt óvatosan addig emeljük, hogy a csecsemő kb. $30^{\circ}$-os szögben feküdjön hátával a takarónak támaszkodva. Ügyelni kell, hogy a takaró emelése lassan, fokozatosan történjék és a csecsemő ne csússzon el rajta. Ezután ebben a helyzetben kell tartani, mert ilyenkor a fej és benne a labirintusok kimozdulnak a fekvő helyzetből a 
gravitáció pedig rövid időn belül hatni kezd. A csecsemő 5-10 másodperc múlva ebből a helyzetből oldalára fordul, majd az oldalfekvő helyzetből a hasára, különösebb zökkenés nélkül. Balról jobbra a jobb, jobbról balra forgatáskor a bal kar néha a hasa alá kerül, és onnan a csecsemő nem húzza ki. A vállcsúcs finom megemelésével elősegíthetjük a kar kihúzását. Vizsgálat közben megítélhető, hogy a csecsemő elfordul-e az oldaláról, menynyi ideig marad oldalfekvésben és onnan hogyan fordul át a mellkasára, illetve a hasára. Hason fekvésben a fej ismét vízszintes helyzetbe kerül és a gravitáció a továbbiakban nem aktivál izommozgást, a labirintus és a vestibulo-spinalis rendszer közvetítésével.

A levegőben felülés emelt fejjel prognosztizálja a későbbi egyenes testhelyzetet, a kúszás és a mászatás a csípő és az alsó végtagok önálló mozgását a későbbi járáshoz. Az elemi járatás pedig összefoglalásként az előzőeket egyszerre reprezentálja. Az esetleges eltérések típusából, fokából, speciális elváltozásaiból prognosztizálható milyen veszélyek fenyegethetik a végleges emberi mozgások kialakulását. Ugyancsak megállapítható, milyen egyéni neuroterápiai programot kell kezdeni ennek megelőzésére, illetve megakadályozására.

Az elemi mozgásminták előrevetítik a későbbi humán-specifikus mozgások és testhelyzetek kialakulásának végleges mintázatait. Mindegyik elemi mozgásminta kiváltható az első 3-4 hónap folyamán! Megszűnésük azt a sorrendet követi, ahogyan a végleges mozgásmintázatok kialakulnak. Például amikor egy csecsemő önállóan kúszni kezd, megszűnik a kúszás elemi mozgásmintája. Jóval később ugyanígy szűnik meg a levegőben ülés mozgásmintája emelt fejjel, amikor a csecsemő először ülésbe kapaszkodik és emelt fejjel ülni tud. Az elemi mozgásmintákban észlelt eltérések prognosztikailag elöre vetítik azokat az elváltozásokat, amelyek a végleges mozgás mintázatokban kialakulhatnak. A lógva maradó fej a felülés és az ülés végleges mozgásmintája kapcsán sem változik, ezzel megakadályozza az egyenes testtartást és a legfontosabb érzékszervek megfelelő működését.

A mozgásdinamikai károsodások neuroterápiája: A csecsemő mozgása különböző izomcsoportok aktivitásából áll. Az első két hónapban ezek a mozgások rendezetlennek tűnnek, de az ujjak mozgásától a fej mozgatásáig a müködő izmok gyakoroltatása rendszeresen folyik. Újszülött kortól fogva - kezelésképpen - a vesztibuláris rendszer aktiválásával izomcsoportok együttes mozgásának kombinációja is gyakoroltatható. Ezek a mozgáskombinációk az elemi mozgásminták. Az esetenként megállapított, korai diagnózis és prognózis alapján olyan korai mozgásterápiát kell választani az elemi mozgásminták aktiválása útján, amely kialakíthatja a hiányzó izommozgásokat. A fejlődésneurológiai mozgásterápiának tehát mindenképpen igazodnia kell ahhoz, hogy melyik elemi mozgásmintában észlelhető elégtelen, illetve csökkent müködés. Elsősorban azoknak az elemi mozgásmintáknak gyakoroltatása szükséges, amelyekben - ismételt vizsgálatok alapján - a kivitelezés hiányosságát biztosan sikerült megállapítani. Az agysérülés a későbbi mozgásminták kialakulásának épségét veszélyezteti, a feladat ezek elemi formájának, az elemi mozgásmintáknak a rendszeres gyakorlása. Tekintettel a rendszeres ismétlés fontosságára a kezelést csak a szülő végezheti a Fejlődésneurológiai Osztályon történt előzetes betanítás, rendszeres ellenőrzés alapján. A fő feladat tehát a csecsemő kivizsgálása és a leletek értékelése alapján a szülők képzése a kezelés módszereinek alkalmazására.

Epilepszia: A korai agyi károsodások egyik következménye epilepszia kialakulása lehet. Távolról sem minden görcsroham számít epilepsziának, ezt a diagnózist csak video-EEG vizsgálat alapján lehetséges felállítani. Az epilepszia kezelésében a legfontosabb a megfelelő gyógyszer kiválasztása, a görcsrohamok típusának, a beteg korának és állapotának ismeretében. Éppen ezért lényeges, hogy minden olyan 
csecsemő, akinél görcsgyanús jelenség miatt a koraszülött-, vagy újszülött osztályon gyógyszeres beállítás történt és elbocsájtáskor még szájon át gyógyszert szed, videoEEG vizsgálatban részesüljön. A video-EEG vizsgálat és a csecsemő klinikai megfigyelése alapján merül fel az akut állapot miatt beállított gyógyszer esetleges leállítása. A vizsgálat kivitelezéséhez biztosítani kell a gyógyszerek kiürülését a gyógyszerkezelés leállításával és a gyógyszer vérszintjének ellenőrzésével. Ezután ismételt videoEEG vizsgálat végzése szükséges! A klinikai görcsjelenség hiánya és a negatív agyi elektromos tevékenység esetén gyógyszeres kezelés nem szükséges. Más a helyzet, ha az előzetesen beállított és általában nyugtató és tonuscsökkentő hatással is bíró gyógyszer kiürülésével párhuzamosan görcstevékenység jelentkezik és az EEG is kóros eltérést mutat. Ilyenkor olyan görcsellenes szer beállítása szükséges, mely gátolja a rohamok megjelenését és viszonylag kevés mellékhatással rendelkezik mind az éberségi szint, mind az izomtónus vonatkozásában. Az agyi károsodás nem csak epilepsziát okozhat, hanem a figyelmi és precognitív müködés, valamint a mozgás-szabályozásában is okozhat kóros tüneteket. Ezeknek a tüneteknek kezelése az epilepszia gyógyszeres ellátása alatt is szükséges! Ügyelni kell arra, hogy az anticonvulsiv gyógyszerek általában csökkentik az agy aktivitását, bizonyos fokú álmosságot, gyengeség érzetet is előidézhetnek, ami befolyásolja a többi tünet kezelését. A gyógyszer megválasztásánál az agyi károsodás összes tünetének kezelhetőségét is figyelembe kell venni.

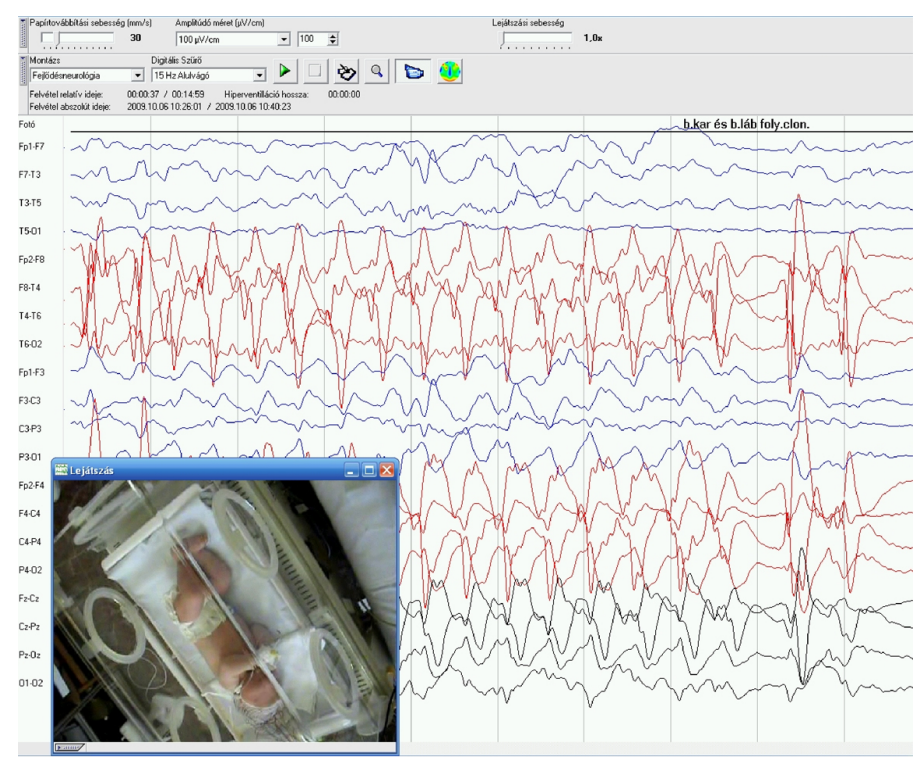

6. kép: Epilepsziás EEG és a vizsgált csecsemő görcsös mozgása

A fejlődésneurológia nemcsak az agyi, agytörzsi (idegi eredetű nyelésbénulás), hanem a gerincvelői, illetve a perifériás idegrendszeri károsodások korai diagnosztikájával és megelőző neuroterápiájával is foglalkozik. Ezekbe a kategóriákba tartoznak a myelomeningocelevel (MMC) született csecsemők, illetve a születés közben a nyaki idegfonat (plexus brachialis) sérülése utáni állapotban szenvedő újszülöttek.

MMC: A Fejlődésneurológiai Osztály 24 órás szolgálatot tart az MMC-vel születettek azonnali, 24 órán belüli teljes kivizsgálására, annak érdekében, hogy még az első 24 órában megtörténhessen a fejlődési rendellenesség sebészeti ellátása. Tapasztaltunk szerint súlyos alsóvégtag elváltozás mellett is lehet teljesen ép hólyagmüködés. A sebészi beavatkozást végzőknek mindezt tudniuk kell ahhoz, hogy megfelelő mútéti módszereket válasszanak a meglévő funkciók megőrzése érdekében. Mütét 
után a fejlődésneurológiai kivizsgálásra és kezelésre felvett MMC-s csecsemők komplex vizsgálata a csípők, az alsó végtagok működésének megállapításából és a hólyag-, illetve a végbél funkcióinak méréséből áll. Az előbbihez az elemi mozgásminták alkalmasak, mert ezek különböző helyzeteiben például kúszás, illetve mászás kiváltásakor objektíven eldönthető az alsó végtagi bénulás mértéke. Amennyiben mindkét oldalon, vagy egy oldalon müködésbeli károsodás észlelhető, úgy a neuroterápiához az alsó végtag funkciókat aktiváló elemi mozgásminták gyakoroltatásán kívül, az érintett végtag idegfelőli, szelektív ingerárammal történő elektroterápiája is hozzá tartozik. A hólyagműködés kivizsgálása EEG-vel kombinált neuro-urodinámiás méréssel történik. Poligráfiával (több csatornás vizsgálóberendezéssel) történő kivizsgálás azt is mérhetővé teszi, hogy a hólyag steril folyadékkal történő feltöltése, vagy a hólyagfal receptorainak elektromos ingerlése kivált-e vegetatív választ az agyi hullámokban. A végbél müködés vizsgálata is elektro-manometriával történik. Mind a hólyag-, mind a végbél-müködés károsodásainak kimutatásához külön kell értékelni a simaizom és a harántcsíkolt izom reakcióit. A hólyag- és/vagy a végbél bénulás jellegének megállapítását követően rendszeres elektroterápia indul a kiesett működés helyreállítása, illetve a másodlagos károsodások kivédése érdekében.
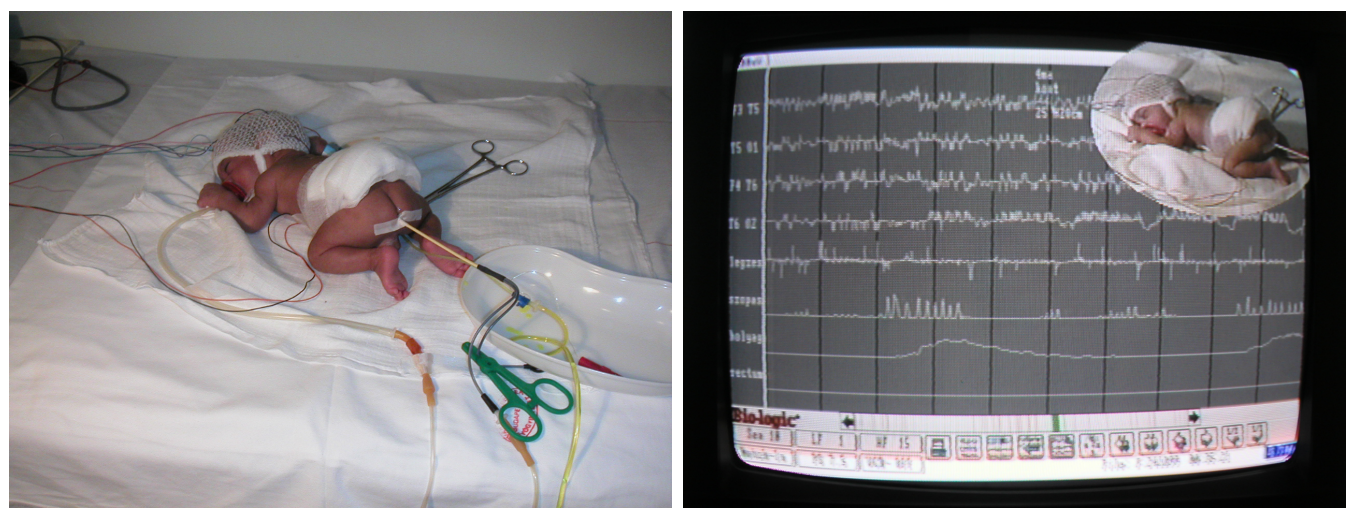

7. kép: Újszülött MMC-s urodynamikai vizsgálata

Plexus brachialis károsodás: Születéskor elszenvedett perifériás idegkárosodás vizsgálatakor meg kell állapítani milyen mértékủ eltérés alakult ki, mert a terápia is ettől függ. Az elváltozás legenyhébb fokán az idegsejt tengelyfonala, axonja sérült, ez az állapot, amelyet neuroapraxiának hívnak, rendszerint hosszabb rövidebb idő alatt kezelés nélkül is meggyógyulhat. Azonban komolyabb sérüléskor a tengelyfonal velöshüvelyével együtt károsodik. Ebben az esetben már kezelésre van szükség, mert az ideg degenerálódik és helyreállító folyamatának, a regenerációnak támogatására van szükség. Ilyen esetekben a neuroterápia rendszeres, napi idegpont felöli elektroterápia alkalmazásából és azoknak az elemi mozgásmintáknak gyakoroltatásából áll, amelyek a felső végtagok müködését aktiválják. A legsúlyosabb plexus sérülés a felső idegköteg egy részének teljes degenerációját okozhatja és ezekben az esetekben mütéti beavatkozás is szükséges. 


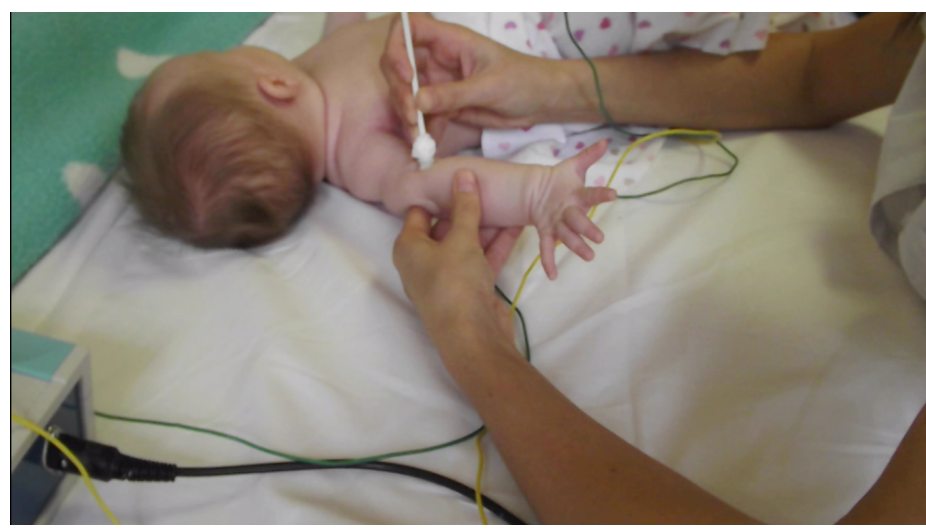

8. kép: Plexus brachialis laesio elektroterápiája idegpont felöli ingerléssel

Kapcsolat a szülökkel, a szülők oktatása: A szülök bevonása a vizsgálatokba és a kezelésbe elengedhetetlen a megfelelő kezelési eredmények eléréséhez. A központi idegrendszer fejlődést veszélyeztető károsodásainak neuroterápiájához rendszeres, egy napra többszöri alkalomra beosztott kezelés szükséges. A központi idegrendszer működésének egyik legfontosabb alaptörvénye a rendszeresség, a rendszeres működtetés, mert ami nem kap rendszeresen ingert annak müködése elvész. Idegrendszerileg károsodott csecsemők esetében ez a törvényszerüség úgy módosul, hogy ami nem kap megfelelő ingert az ki sem alakul (use it or lose it). Ezt a szükséges rendszerességet a funkciók kialakítására csak a szülők, rendszerint az édesanya tudják biztosítani. A család részére ennek a rendszeres kezelésnek a megszervezése általában komoly problémát okoz, amelyet a felnövekvő utód, illetve a család érdekében meg kell oldani. A szülök, az édesanyák nagy része megérti, hogy csak ez a befektetett munka térülhet meg a csecsemő idegrendszeri fejlődésének kiépítésében, az értelmi és a mozgásbeli adottságok kialakításában. Az édesanyák nagy része kivizsgálás alatt is a Fejlődésneurológiai Osztályon tartózkodik, napközben együtt van a csecsemővel és a szoptatók éjszaka is a kórházban laknak. A megértésen kívül természetesen tudásra is szükség van a kezelés rendszeres elvégzéséhez. Az osztályon dolgozó csapatok (teamek) orvosai, gyógytornászai, gyógypedagógusai, illetve pszichológusai igyekeznek mindazt elmagyarázni az édesanyának, amennyit a csecsemő állapotáról tudnia kell, a kezelés szükségességének megértéséhez. Az osztályon rendszerint egyegy ilyen munkacsoport foglalkozik egy csecsemővel és a későbbiekben is ugyanazok a személyek vizsgálják a járóbeteg-rendelésen a fejlődés menetének ellenőrzése közben. A gyógytornászok azok, akik részletesen megmutatják a mozgással kapcsolatos feladatatok elvégzését és a szülőkkel is elvégeztetik a kezelési gyakorlatokat, hogy rutint szerezzenek az otthoni kezelés számára. A gyógypedagógus, illetve pszichológus magyarázza el ugyanezt a szülőnek a figyelmi funkciók és a prekognitív müködések aktiválásához. Azok a feladatok, amelyek ezekhez szükségesek ugyancsak megértést és gyakorlatot kívánnak. 


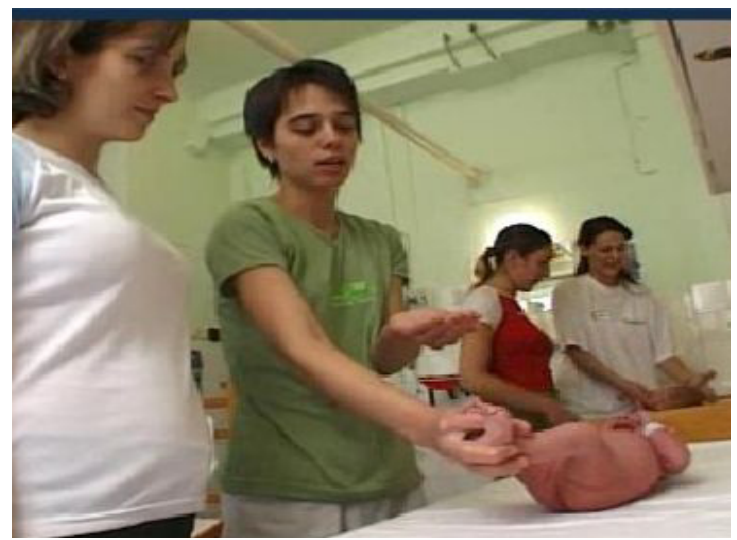

9. kép: Szülők oktatása az elemi mozgásminták otthoni rendszeres végeztetésére

Korai neuroterápia, korai intervenció, korai fejlesztés: A három fogalomkör feladatainak végzése nem zárja ki egymást, azonban rendkívül fontos a múveletek időzítése. Agyi károsodásban, gerincvelői fejlődési rendellenességek és perifériás idegsérülések eseteiben először huzamosabb ideig tartó neuroterápiára van szükség. A neuroterápia elsősorban az agyi károsodásokban szenvedő újszülötteknél és fiatal csecsemőknél napi több órás rendszeresen beosztott foglalkozást igényel. Ezt csak megfelelő kivizsgálást követően, orvosi ellenőrzés mellett betanított szülő végezheti. Ez alatt az idő alatt mindennemú intervenció, illetve fejlesztés messzemenően csökkenti a terápiára fordított időt és ezáltal veszélyezteti a neuroterápia hatékonyságát. Kezelésben azokat kell részesíteni, akiknek fejlődését a központi-, vagy a perifériás idegrendszer károsodása veszélyezteti. A fő feladata azoknak a funkcióknak kiépítése, amelyek normális kialakulását a károsodás veszélyezteti. Esetenként ez biztosan igénybe veszi az első másfél évet, ami alatt a beteg rendszeres vizsgálatokban és a hozzátartozók a kezelési programok szükség szerinti változtatásában részesülnek. $\mathrm{Az}$ életkornak megfelelő funkciók sikeres teljes, vagy legalábbis részleges neuroterápiája után adott az alkalom intervencióra, illetve fejlesztésre. Ezek még mindig korai időszakok, hiszen kisdedekről, kis gyermekekről van szó. A lényeg tehát a neuroterápia, az intervenció, illetve a fejlesztés korai időszakai összekeverésének megelőzése, megakadályozása. Az intervencióval, illetve a fejlődéssel foglalkozó gyógypedagógusnak, vagy más szakképesített személynek természetesen ismernie kellene az előzőekben neuroterápiában részesült különböző életkorú személy betegségének részleteit a neuroterápia alkalmazott módszereit és az elért eredményeket. Ilyen esetekben erre az előzetes kezelésre és eredményekre szükséges ráépíteni az általa alkalmazott módszereket. A Fejlődésneurológiai Osztály minden esetben rendelkezésre bocsájtja, akár személyes megbeszélés alapján is a szükséges információkat.

\section{Irodalom}

Berényi Marianne és Katona Ferenc (2012): Fejlődésneurológia - Az öntudat, a kommunikáció és a mozgás kialakulása. Medicina Kiadó, Budapest. 